\title{
Hopland celebrates 50 years of rangeland research
}
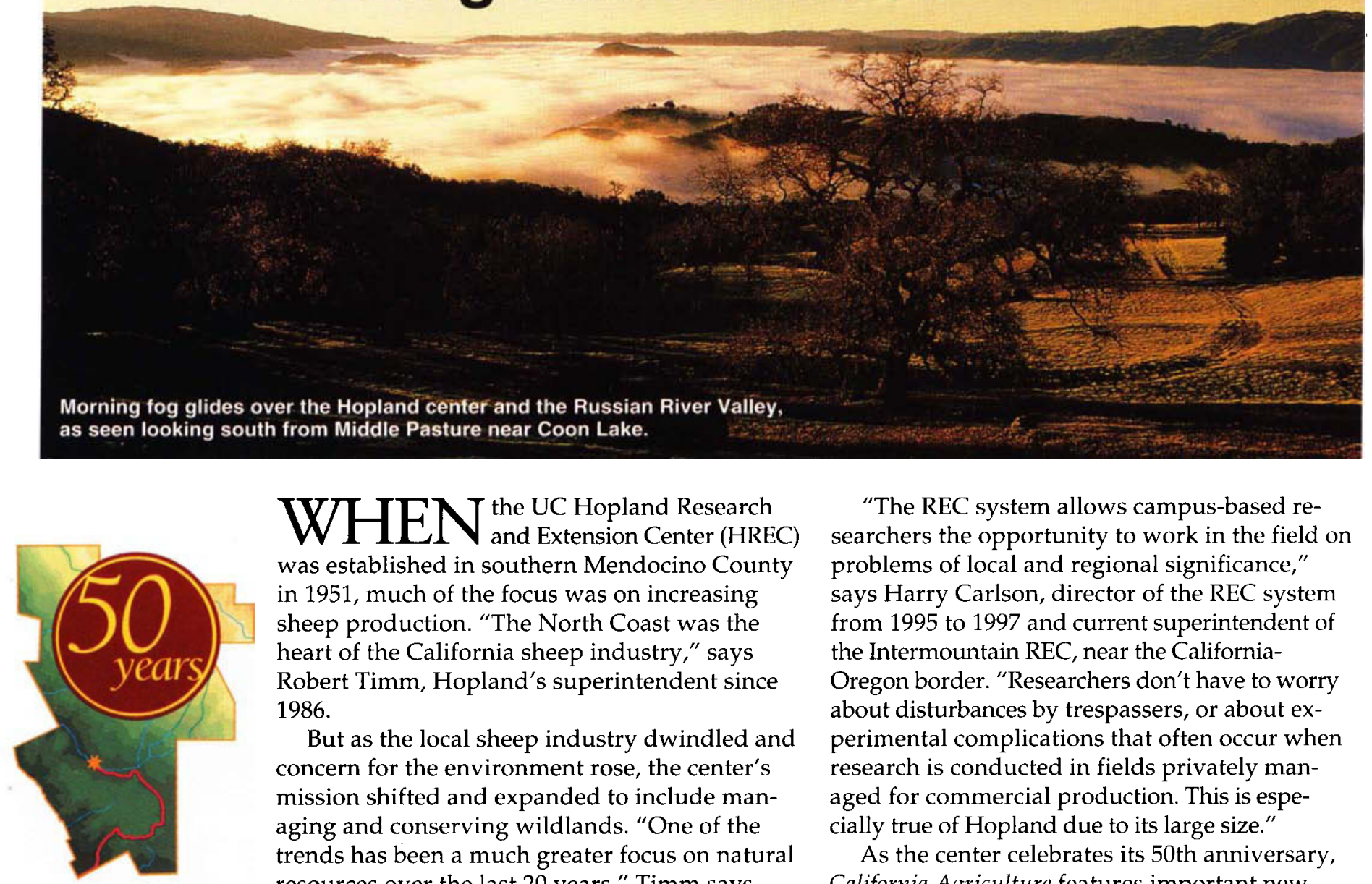

WHEN was established in southern Mendocino County in 1951, much of the focus was on increasing sheep production. "The North Coast was the heart of the California sheep industry," says Robert Timm, Hopland's superintendent since 1986.

But as the local sheep industry dwindled and concern for the environment rose, the center's mission shifted and expanded to include managing and conserving wildlands. "One of the trends has been a much greater focus on natural resources over the last 20 years," Timm says.

Hopland is an ideal place for studying how to manage North Coast natural resources. Located about 30 miles inland from the Pacific Ocean, the 5,358-acre center is geographically and biologically diverse. The rugged terrain ranges from 500 to 3,000 feet in elevation, and has a variety of vegetation types including grassland, chaparral and hardwood forest, as well as wetlands, Parson's Creek, springs and vernal pools. The wildlife is equally varied, with more than 600 species of plants, 200 birds, 40 mammals, 27 reptiles and amphibians, and eight fish, including steelhead trout.

The University began establishing what are now called Research and Extension Centers (RECs) in 1912 to facilitate research on agriculture and natural resources. The 10 RECs, previously known as field stat: ons, represent the major crop-production and climate regions of the state, with individual RECs specializing in tree fruit and vine crops, field and vegetable crops, and livestock production and natural resource management (see p. 3).
"The REC system allows campus-based researchers the opportunity to work in the field on problems of local and regional significance," says Harry Carlson, director of the REC system from 1995 to 1997 and current superintendent of the Intermountain REC, near the CaliforniaOregon border. "Researchers don't have to worry about disturbances by trespassers, or about experimental complications that often occur when research is conducted in fields privately managed for commercial production. This is especially true of Hopland due to its large size."

As the center celebrates its 50th anniversary, Califormia Agriculture features important new and ongoing research conducted at Hopland.

\section{A half-century of research}

An annotated bibliography based on research conducted at the HREC through 1999, which is scheduled for publication in 2002, contains more than 1,000 entries, says UC Berkeley Professor Robert Lane, chair of the HREC Research Advisory Committee.

"A perusal of this compilation underscores the multidisciplinary nature of many research projects at Hopland," says Lane, who has been working at the center since beginning his doctoral research there in 1970 . For example, investigations of human tick-borne diseases (such as Rocky Mountain spotted fever and Lyme disease) initiated in 1974 have involved such disparate disciplines as acarology, bacteriology, microbiology, virology, immunology, ecology, herpetology, mammalogy, ornithology and molecular biology (see p. 13).

In 1976, there were 21 research projects distributed among five principal categories at 


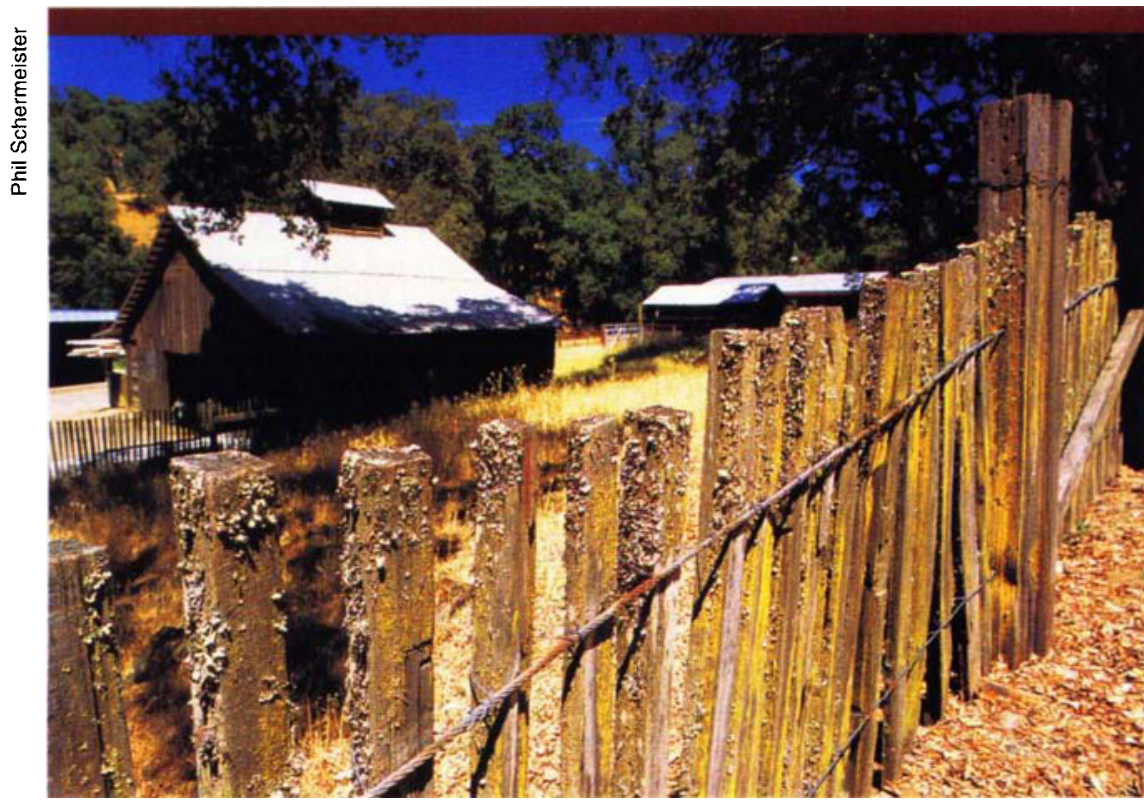

cludes more than 30 years of genetic research (see p. 19). One of the main goals was to develop sheep breeds that were welladapted to North Coast conditions, with an emphasis on lamb and wool production. While this work was successful, it has limited usefulness in the region today. "Unfortunately, the local sheep industry is no longer economically

Hopland, the great majority of which represented animal science, range management, or entomology and parasitology. By 2001, however, the number of projects had expanded to 37 with the emergence of two additional distinct categories, natural resources and plant science. "Today, projects involving natural resources science and environmental

management comprise a sizeable proportion of the project mix at Hopland," Lane says.

Some of the new knowledge emerging from these studies received immediate application regionally, nationally or globally. For instance, research conducted on anthelmintics (deworming agents) during the 1950 s and 1960 s benefited both the sheep industry and pharmaceutical science. Some field studies have been designed to find solutions to current management problems: a recent agroforestry project demonstrates how livestock grazing and tree farming may be conducted simultaneously to increase producer returns and limit pressure to subdivide rangeland (see p. 37), while longterm trials with Australian clover cultivars are providing important information on the usefulness of these legumes to improve North Coast rangelands (see p. 60). On the other hand, research of a more basic and long-term nature expands our understanding of biological and physical processes in natural and humanmodified ecosystems.

\section{Sheep breeding and predator control}

While it is no longer the primary focus, sheep-related research at Hopland continues to provide critical insights for producers and range managers. Hopland's sheep work in- viable except on a small scale," Timm says.

The industry's decline can be attributed to several factors: increased competition from Australia and New Zealand (a result of trade globalization), falling lamb and wool prices, rising production costs and increasing predation on sheep, particularly on lambs. At the HREC, coyotes were found to cause about three-quarters of the predator-related sheep deaths in the 1970s and 1980s. USDA and UC Berkeley researchers discovered that most of the deaths were caused by dominant breeding pairs, and scientists at Hopland worked on methods to target these coyotes selectively (see p. 26 and 32 ).

The decline of the North Coast sheep industry contributed to a shift in Hopland's animal science work. Now, the emphasis includes using sheep and goats rather than herbicides to control brush. "Natural resource values have become fully integrated into our agricultural mission," Timm says.

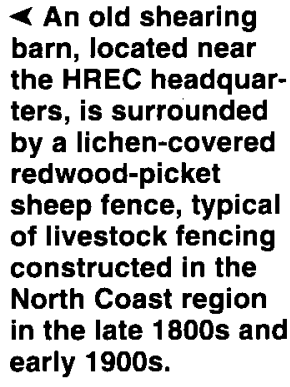

On June 9, 2001, more than 200 Hopland staff and scientists from past and present gathered at the HREC to celebrate its 50 th anniversary. There were sheep-herding and sheep-shearing demonstrations, field tours and a lamb lunch.

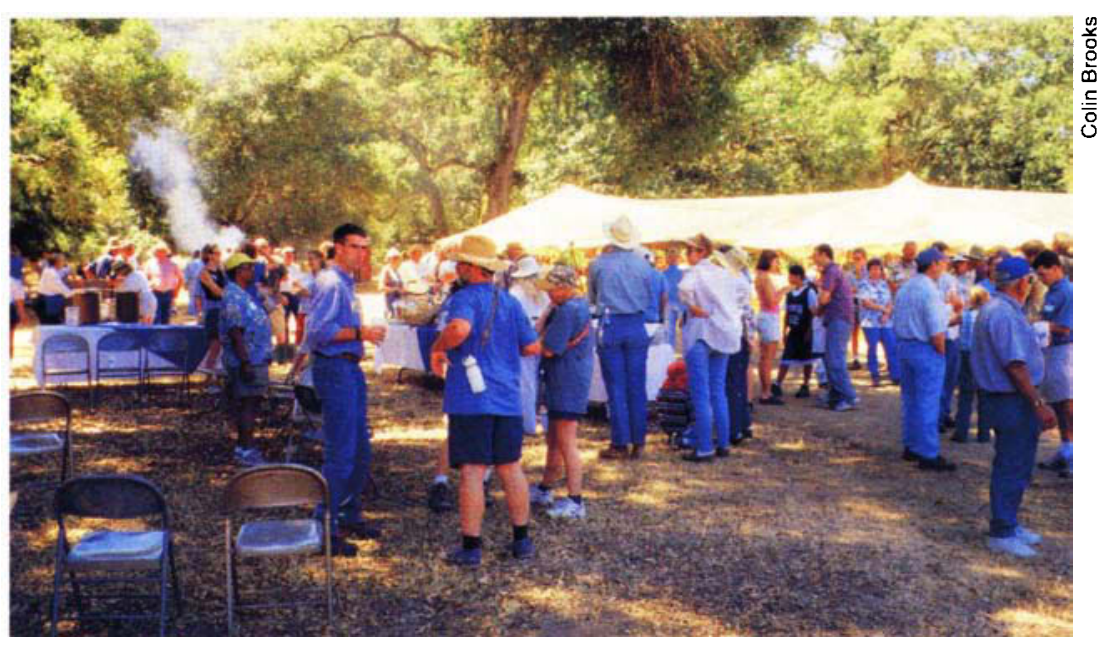




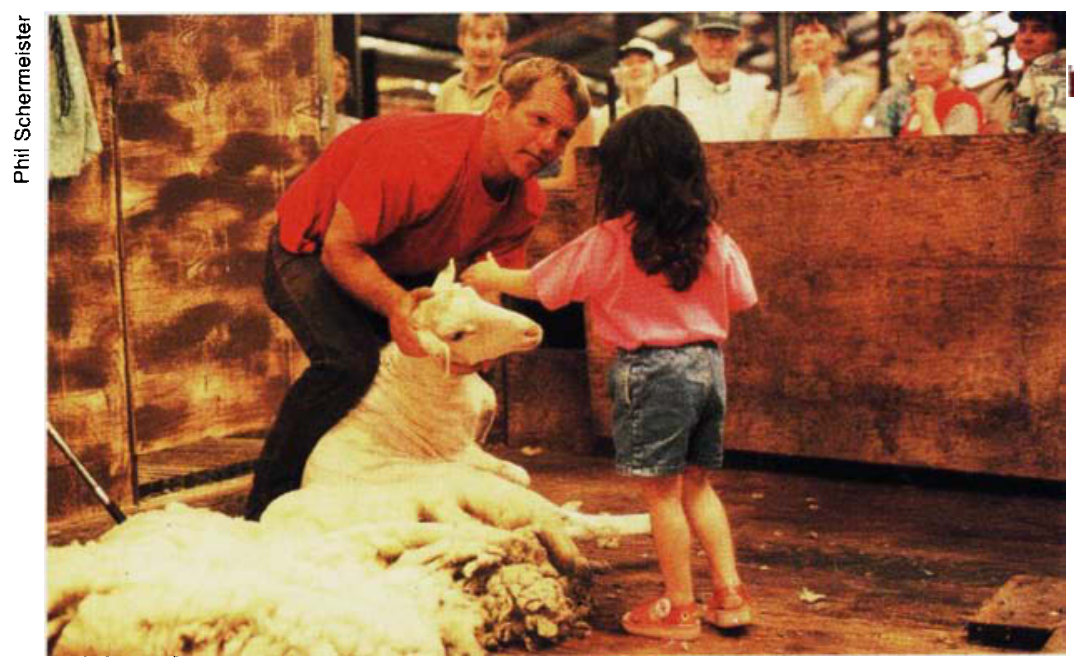

A young visitor gets a close look at a ewe being shorn by sheep shearer Chris Cornett of Tomales, Calif. during the 50th-anniversary celebration.

\section{Rangeland research}

Initial baseline studies conducted in the 1950s showed that Hopland's natural forage production was extremely variable. While a sheep could get enough to eat from just 1 acre during some years, in other years it took 20 acres to support a single sheep. Hopland researchers wanted to increase forage production, and one of the center's first studies showed that seeding pastures with nitrogen-fixing subterranean clover increased forage production more than fertilizing with nitrogen.

"This is also cheaper and better for the environment," says UC Berkeley graduate student Valerie Eviner. "This kind of win-win situation is rare - it's inspiring. And Hopland has provided that from the beginning."

Eviner is continuing the Hopland tradition of finding ways to manage soil problems with plants (see p. 54). While the conventional wisdom is to focus on one soil problem at a time, she is discovering that multiple soil problems can be alleviated simultaneously by using the right combination of plants. For instance, by planting softchess (a nonaggressive grass) and clover, rangeland managers can both control erosion and increase nitrogen.

Scientists are also studying how to control barb goatgrass, an extremely aggressive introduced species that is invading Northern California and swept over most of Hopland about 10 years ago (see p. 47). Eradicating goatgrass is a high priority because the mature plants are not palatable to wildlife and livestock, unlike some other non-native rangeland plants.

\section{Watersheds and water quality}

Soon after Hopland was established, researchers began long-term studies of watershed management at two sites: one that had porous soils (Watershed I) and one that did not (Watershed II). "Basically, it was decided that the native vegetative cover would be replaced with a cover more economical in water use and more productive for livestock," wrote Alfred Murphy, Hopland's superintendent from 1951 to 1986 , in a 1976 California Agriculture special issue.

This meant converting woodlands to grassland. "Back in the fifties, oak trees on rangelands were regarded as weeds," Timm says. The researchers cut more than 10,000 oak trees to the ground at one of the sites and killed them with herbicides at the other. Next they bulldozed the brush, burned the woody debris, and seeded the cleared land with forage plants.

While Watershed I - with its porous soils was stable after being converted to grassland, Watershed II was a different story. Before the conversion, its soil had also been stable. However, afterward there were 61 landslides in a decade, and stream sedimentation increased 10-fold (from an average of 400 to 4,000 tons per year). "We learned that erosion was highly dependent on the soil type," Timm says.

Now scientists are using Hopland watersheds to study how to improve rangeland water quality (see p. 64). After collecting baseline data in seven small watersheds, they will determine the effects of various treatments, such as prescribed burning and changes to the grazing regime. One indicator of water quality will be the number of steelhead trout that return from the ocean to spawn in Parson's Creek, a tributary of the Russian River.

Hopland research is also helping to improve the water quality at nearby Clear Lake, which gets a small amount of its water from Hopland watersheds. "Hopland used to relate directly to agricul-

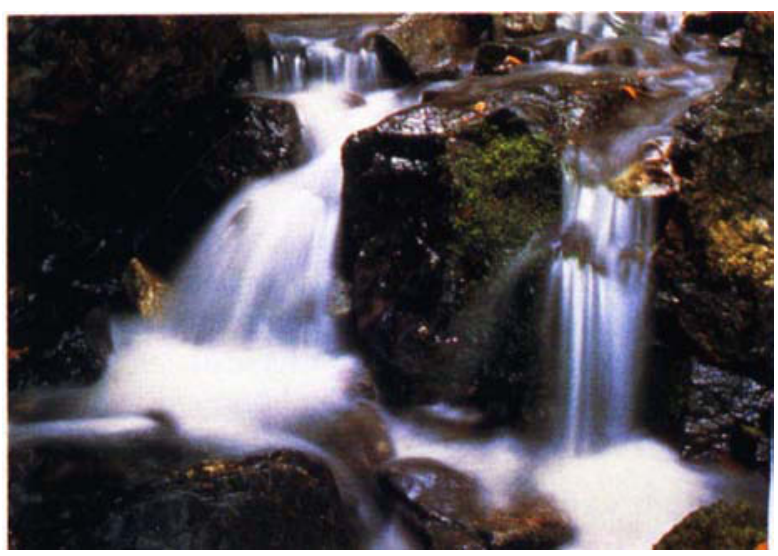

Scientists are studying Hopland watersheds to learn how various land uses affect water quality, soil erosion and other factors. Runoff from winter precipitation flows in one of hundreds of small drainages at Hopland. 
ture. The greater effort in natural resources management reflects public sentiment," says Hopland staff research associate Chuck Vaughn, who has worked there since 1973.

During the dry years of the 1990s, extensive blue-green algae mats grew in Clear Lake. These algae mats rose to the surface and rotted in the fall, smelling so bad in some places that people had to be evacuated. In collaboration with Hopland staff and using the center's laboratory, UC Davis scientists found that algae growth was due primarily to increased phosphorus, much of which came from sediments. The answer to this algae problem has been managing the lake's watershed, an effort involving Lake County landowners.

\section{Habitat restoration}

In 1993, Hopland initiated a demonstration riparian restoration project funded by the California Department of Fish and Game, designed and coordinated by Bob Keiffer, HREC principal superintendent of agriculture. Some sections of Parson's Creek were planted with willow, alder, wild grape and other native species, and selected sections were fenced to exclude sheep or sheep and deer. The restored riparian vegetation is becoming well-established there; this has improved the fish-spawning habitat in Parson's Creek significantly.

Hopland researchers are also studying oak regeneration in one of the watersheds that was converted to grassland in the 1950s. "We used to cut oaks to manage our rangelands, now we're replacing them," Vaughn says.

In the 40-odd years since the land was cleared, evergreen oaks have regenerated on the moist northerly slopes. Deciduous oaks, which favor the drier southerly slopes, have not regenerated. This suggests that deciduous oaks will require active restoration, such as planting and seedling protection, according to Hoplandbased researchers Adina Merenlender and Colin Brooks, of the UC Integrated Hardwood Range Management Program (IHRMP).

Hopland is an important site for studying oaks because it "represents one of the last large, intact oak woodlands in the Coast Range," says IHRMP botanist Kerry Heise, who like Brooks and Merenlender is based at the HREC. Hopland also has among the highest diversity of oaks in the state.

Led by Merenlender, Hopland's IHRMP researchers are mapping, monitoring and forecasting changes to North Coast oak woodlands.
They also hold well-attended UC Cooperative Extension workshops on oak identification, protection and restoration.

\section{Learning center}

Perhaps most importantly, for a half-century Hopland has been a vital center of learning that has provided scientific, educational and employment opportunities for many people. On June 9, 2001, more than 200 of them gathered at Hopland for a 50th-anniversary celebration. Active and retired scientists discussed ongoing research and reminisced about how working at the HREC has influenced their careers and lives. "The beauty of the landscape, the richness of the resources and the opportunity to work and learn in an interdisciplinary environment has made this facility highly productive," Timm says. "For almost everyone who has worked here, Hopland has become a special place."

Over the past 50 years, hundreds of scientists have conducted research at the station, some of whom lived in residences on site and even raised families there. Likewise, the center has provided opportunities for dozens of graduate students, as well as undergraduate interns, to receive training and field experience. Independent study projects, and more than 50 master's theses and doctoral dissertations based on field work conducted at Hopland have not only advanced our scientific knowledge but also have "aided the growth and maturity of many promising students from UC Davis, UC Berkeley and other campuses in ways that are incalculable," Lane says.

Meanwhile, the small resident support staff has included agricultural technicians, shepherds, building maintenance workers, mechanics, administrative assistants and others, some of whom spent their entire careers at the center. "For every field day, every experiment and every publication you'll find our group of UC employees working behind the scenes," Timm says. "It's these men and women, dedicated to the University's mission at this facility, who make it all happen."

$$
\text { - Robin Meadows }
$$

